\title{
INFLUENCE OF WATER HARDNESS ON VOLATILE COMPOUNDS AND SENSORY PROPERTIES OF TURKISH COFFEE
}

\author{
Ceyda Dadalı* \\ Ege University, Engineering Faculty, Food Engineering Department, İzmir, Turkey \\ Received/ Geliş: 17.05.2021; Accepted/ Kabul: 12.08.2021; Published online/ Online bask1: 06.09.2021 \\ Dadal, C. (2021). Influence of water hardness on volatile compounds and sensory properties of Turkish coffee. GID A \\ (2021) 46 (5) 1183-1194 doi: 10.15237/gida.GD21087 \\ Dadalı, C. (2021). Su sertliğinin Türk kahvesinin uçucu bileşenlerine ve duyusal özelliklerine etkisi. GIDA \\ (2021) 46 (5) 1183-1194 doi: 10.15237/gida.GD21087

\begin{abstract}
Water used in coffee preparation has essential importance on coffee flavour. In this study, it was aimed to determine effect of water (soft, medium hard and hard) on volatile compounds and sensory properties of Turkish coffee. It was revealed that number of volatile compounds of Turkish coffee prepared with medium hard water higher than Turkish coffee prepared with soft and hard water. Medium hard water used Turkish coffee contain 30 volatile compounds from aldehyde (2), furan (13), furanone (1), ketone (2), pyrazine (7), pyridine (1), pyrrole (3), and thiophene (1) class. The sweetness and sourness of soft water used Turkish coffee samples were high. Roasted coffee and roasted hazelnut characteristics were perceived intensely in medium hard water used Turkish coffee samples. While bitterness was perceived intensely in hard water used Turkish coffee samples; the intensity of roasted coffee, roasted hazelnut, roasted almond, spicy, citrus, sweet, and sour characteristics were low.
\end{abstract}

Keywords: water hardness, Turkish coffee, sensory property, volatile compound

\section{SU SERTLİĞİNİN TÜRK KAHVESINIIN UÇUCU BİLEŞENLERİNE VE DUYUSAL ÖZELLIKKLERİNE ETKİSI}

\section{ÖZ}

Kahve hazırlamada kullanılan su, kahvenin lezzetinde büyük önem taşımaktadır. Bu çalışmada, suyun (yumuşak, orta sert ve sert) Türk kahvesinin uçucu bileşenleri ve duyusal özellikleri üzerindeki etkisinin belirlenmesi amaçlanmıştır. Orta sertlikte suyla hazırlanan Türk kahvesinin uçucu bileşen sayısının yumuşak ve sert su ile hazırlanan Türk kahvesine göre daha fazla olduğu belirlenmiştir. Orta sertlikte kullanılan Türk kahvesi, aldehit (2), furan (13), furanon (1), keton (2), pirazin (7), piridin (1), pirol (3) ve tiyofen (1) grubundan 30 uçucu bileşen içermektedir. Yumuşak su kullanılan Türk kahvesi örneklerinin tatlılığ1 ve ekşiliği daha fazla algılanırken, orta sertlikte su kullanılan Türk kahvesi örneklerinde kavrulmuş kahve ve kavrulmuş fındık karakterleri yoğun bir şekilde algılanmıştır. Sert su kullanılan Türk kahvesi örneklerinde acılık yoğun hissedilirken, kavrulmuş kahve, kavrulmuş findık, kavrulmuş badem, baharatlı, narenciye, tatlı ve ekşi karakterler daha az algılanmıştır.

Anahtar kelimeler: Su sertliği, Türk kahvesi, duyusal özellik, uçucu bileşen

${ }^{*}$ Corresponding author / Yazışmalardan sorumlu yazar:

$\square$ : ceyda.dadali@gmail.com

(c) (+90) 2323113007

冝: (+90) 2323114831

Ceyda Dadalı; ORCID no: 0000-0003-2102-8582 


\section{INTRODUCTION}

The flavour of coffee is one of the important factors for determining coffee quality and acceptance by consumers (Jelen, 2012). Coffee processing and brewing parameters directly affect coffee flavour, quality, and acceptance. Coffee flavour changes due to some specific brewing parameters namely, extraction time, water quality, temperature, pressure, particle size and coffee/water ratio (Moroney et al., 2015)

Water is one of the important components of coffee brew that comes after roasted coffee. Water type used in coffee brewing influences dissolution and extraction of coffee compounds from coffee brew (Hendon et al., 2014). On the other hand, in many coffee studies the quality of the water used in coffee brew preparation is ignored. It was stated by Specialty Coffee Association of America (SCAA) that the quality of the water used in coffee preparation should be considered. The total dissolved solids (TDS) in the water to be used to brew a good quality coffee is specified by the SCAA. (SCAA, 2009).

Coffee brewing method changes depending on geographic, cultural differences and individual likes, also habits. One of the coffee brewing methods was Turkish coffee brewing prepared according to decoction method. Turkish coffee brewing method involves boiling of water and roasted, fine ground coffee (Petracco, 2001; Hameed et al., 2018; Cordoba et al., 2020). Turkish coffee is consumed in Middle East, North Africa, Caucasus, Balkans, and Eastern Europe (Küçükkömürler and Özgen, 2009). Kıvançlı and Elmac1 (2016), Amanpour and Selli (2016), Elmac1 and Gok (2020), Ayseli et al. (2021), and Akgün et al. (2021) conducted studies on volatile compound and sensory properties of Turkish coffee. L-asparaginase treatment on Turkish coffee volatiles were determied. Kivançlı and Elmac1 (2016) investigated effect of roasting conditions on volatile compounds and sensory properties of Turkish coffee. Amanpour and Selli (2016) compared the volatile profile of Turkish coffee and French press coffee. Ayseli et al. (2021) determined aroma active compound of Turkish coffee brewed from medium and dark roasted coffee.

In the previous studies the effect of water type on coffee quality was evaluated (Gardner et al., 1958; Pangborn ve ark., 1982; Navarini and Rivetti, 2010; Hendon et al., 2014; Fibrianto et al., 2018; Dadalı and Elmac1, 2021). On the other hand, the effect of water hardness on Turkish coffee has not been investigated yet. The aim of this study was to determine the influence of water having different hardness values on volatile compounds and sensory properties of Turkish coffee.

\section{MATERIALS AND METHODS}

\section{Materials}

Medium roasted, fine ground Arabica coffee (Coffea arabica L.) (Black Ivory) was used for Turkish coffee preparation. Turkish coffee samples were prepared with bottled water (Nestle), purified water, medium hard mains water, and hard mains water. Divinylbenzene/Carboxen/Polydimethylsiloxane (DVB/CAR/PDMS) fiber and C7-C30 alkane mixture were obtained from Supelco.

\section{Methods}

\section{Turkish coffee preparation}

Turkish coffee samples were prepared with automatic Turkish coffee brewing machine (Arçelik). A total of $5 \mathrm{~g}$ roasted ground coffee and $65 \mathrm{ml}$ of bottled water (Nestle), purified water, medium hard mains water, and hard mains water used for Turkish coffee preparation.

\section{Water hardness determination}

The hardness value of water samples was determined according to 973.52 numbered EDTA titrimetric method (AOAC, 1990). Total dissolved solids (TDS) of water samples were also determined by TDS meter (TDS-3).

\section{Head space-solid phase microextraction (HS-SPME)}

Volatile compounds of Turkish coffee prepared with water having different hardness values was extracted by HS-SPME. The extraction was implemented by using 50/30 $\mu \mathrm{m}$ DVB/CAR/PDMS fiber. For volatile compound analysis, $20 \mathrm{ml}$ of Turkish coffee sample was used. 
The prepared coffee was placed in a $40 \mathrm{ml}$ vial and sealed with a PTFE coated silicon septum. The vial was placed on the block heater at $60^{\circ} \mathrm{C}$ and the fiber was held in the headspace of the vial for 30 minutes. The desorption of volatile compounds adsorbed on the fiber was achieved using Gas Chromatography-Mass Spectrometry (GC-MS) (Dadalı and Elmac1, 2021).

\section{GC-MS analysis}

The volatile compound analysis was implemented using GC-MS (HP 6980 GC/HP-5973MS, Agilent Technologies). Temperature of injection port was $250^{\circ} \mathrm{C}$. A DB-WAX $(60 \mathrm{~m} \times 0.25 \mathrm{~mm}$, $0.50 \mu \mathrm{m}$ film thickness, Agilent Technologies) capillary column was utilized for GC-MS analysis. The oven temperature program started at $50^{\circ} \mathrm{C}$ and was hold at $50^{\circ} \mathrm{C}$ for 2 minutes. The temperature was increased from $50^{\circ} \mathrm{C}$ to $90^{\circ} \mathrm{C}$ with an increase of $5^{\circ} \mathrm{C} / \mathrm{min}$ and from $90^{\circ} \mathrm{C}$ to $220^{\circ} \mathrm{C}$ with an increase of $2^{\circ} \mathrm{C} / \mathrm{min}$ and kept at $220^{\circ} \mathrm{C}$ for 10 minutes. Helium was used as carrier gas and the flow rate was $1.6 \mathrm{ml} / \mathrm{dk}$ (Akiyama ve ark., 2008). Identification of volatile compounds were performed by WILEY and NIST libraries and Kovats index of volatile compounds was determined using C7-C30 alkane mixture.

\section{Sensory analysis}

The sensory evaluation of Turkish coffees prepared using water having different hardness values was carried out according to descriptive sensory analysis method (Altuğ Onoğur and Elmac1, 2015). Sensory analysis was carried out with the participation of 8 trained assessors aged between 21-57. The assessors were trained in eight sessions which continued 45 minutes. Descriptive sensory characteristics of Turkish coffee were developed during training panels. Turkish coffee samples were served in white porcelain cups. Eighty $\mathrm{ml}$ of prepared Turkish coffee samples were presented to each panellist at $65^{\circ} \mathrm{C}$. The sensory characteristics and references used in the sensory evaluation of Turkish coffee samples are given in Table 1. The intensity of sensory attributes was evaluated using 0-50 $\mathrm{mm}$ graphical scale during sensory evaluation.

Table 1. Sensory characteristics and references used in sensory evaluation of Turkish coffee

\begin{tabular}{ll}
\hline Sensory characteristics & Reference \\
\hline Roasted coffee & Roasted coffee \\
Roasted hazelnut & Roasted hazelnut \\
Roasted almond & Roasted almond \\
Vegetable & Raw mushroom \\
Spicy & Nutmeg \\
Earthy & Earth \\
Citrus & Orange \\
Sweet & Sucrose solution $(1.00 \%)$ \\
Sour & Citric acid solution $(0.15 \%)$ \\
Bitter & Caffeine solution $(0.02 \%)$ \\
\hline
\end{tabular}

\section{Statistical analysis}

Statistical evaluation of water and Turkish coffee samples was performed by SPSS 20.0 package program. Statistical differences of analysis results were determined using ANOVA (Analysis of Variance) and Duncan multiple range test. Cluster analysis and principal component analysis (PCA) were applied to volatile compound and sensory analysis results. Cluster analysis and PCA were implemented using XLSTAT 2021.

\section{RESULTS AND DISCUSSION Water hardness}

The hardness values of water samples are shown in Table 2. There was a significant difference among hardness values of water samples and also TDS values of water samples $(p<0.05)$. While purified water had the lowest hardness and TDS values, the hardness and TDS values of the mains water samples were higher at statistically significant level $(P<0.05)$. Also, the hardness and TDS value of bottled water were determined lower than mains water samples $(P<0.05)$. 
Table 2. Hardness and TDS values of water samples ${ }^{1}$

\begin{tabular}{lcc}
\hline Water sample & Hardness value $(\mathrm{mg} / \mathrm{L}$ CaCO3) & TDS value $(\mathrm{mg} / \mathrm{L}$ TDS $)$ \\
\hline Soft water (purified) & $13.65 \pm 0.66^{\mathrm{a}}$ & $32.33 \pm 0.47^{\mathrm{a}}$ \\
Soft water (bottled) & $25.13 \pm 1.80^{\mathrm{b}}$ & $51.17 \pm 1.43^{\mathrm{b}}$ \\
Medium hard water (mains) & $79.81 \pm 2.05^{\mathrm{c}}$ & $161.33 \pm 1.25^{\mathrm{c}}$ \\
Hard water (mains) & $166.38 \pm 3.70^{\mathrm{d}}$ & $465.67 \pm 2.49^{\mathrm{d}}$ \\
\hline${ }^{1}:$ Analysis results were expressed as mean \pm standart deviation. The values with same letters within the same column \\
are statistically similar $(P>0.05)$
\end{tabular}

\section{Volatile compounds}

Volatile compounds determined in Turkish coffee brew prepared with soft, medium, and hard water are shown in Table 3. Volatile compounds from the aldehyde, furan, furanone, ketone, pyrazine, pyridine, pyrrole and thiophene groups were detected in Turkish coffee samples. It was determined that the water used in the preparation of coffee affects the number of volatile compounds found in Turkish coffee. The highest number of volatile compounds were determined in Turkish coffee prepared with medium hard water. Turkish coffee prepared with medium hard water contains 30 volatile compounds, including 2 aldehydes, 13 furans, 1 furanone, 2 ketones, 7 pyrazine, 1 pyridine, 3 pyrrole and 1 thiophene group. No statistically significant difference was detected in the number of volatile compounds between Turkish coffees prepared with soft water. A total of 29 volatile compounds (2 aldehydes, 12 furans, 1 furanone, 2 ketones, 7 pyrazine, 1 pyridine, 3 pyrrole, and 1 thiophene) were detected in these coffee brews. Turkish coffee prepared with hard water contained the least number of volatile compounds was (27 volatile compounds) namely; 2 aldehydes, 12 furans, 1 furanone, 1 ketone, 7 pyrazine, 1 pyridine, 2 pyrrole and 1 thiophene. In agreement with this study Dadalı and Elmac1 (2021) determined highest number of volatile compounds in filter coffee prepared with medium hard water. On the other hand, the number of volatile compounds determined in this study was less than the number of volatile compounds determined by Ayseli et al. (2021) and Akgün et al. (2021). The coffee beans used in the different studies were obtained from different sources and this might have caused the differentiation in the number of volatile compounds detected.

Table 3. The area percentage of volatile compounds of Turkish coffee samples prepared with waters having different hardness values ${ }^{1}$

\begin{tabular}{llcccc}
\hline $\begin{array}{l}\text { Kovats } \\
\text { index }\end{array}$ & Volatile compound & $\begin{array}{c}\text { Soft water } \\
\text { (purified) }\end{array}$ & $\begin{array}{c}\text { Soft water } \\
\text { (bottled) }\end{array}$ & $\begin{array}{c}\text { Medium hard } \\
\text { water (mains) }\end{array}$ & $\begin{array}{c}\text { Hard water } \\
\text { (mains) }\end{array}$ \\
\hline & Aldehyde & & & & \\
927 & 2-Methylbutanal & $1.05 \pm 0.03^{\mathrm{c}}$ & $0.96 \pm 0.03^{\mathrm{bc}}$ & $0.83 \pm 0.06^{\mathrm{ab}}$ & $0.76 \pm 0.02^{\mathrm{a}}$ \\
1557 & $\begin{array}{l}\text { Benzaldehyde } \\
\text { Total }\end{array}$ & $0.65 \pm 0.08^{\mathrm{a}}$ & $0.64 \pm 0.02^{\mathrm{a}}$ & $0.68 \pm 0.03^{\mathrm{a}}$ & $0.58 \pm 0.00^{\mathrm{a}}$ \\
& Furan and furanone & $1.70 \pm 0.05^{\mathrm{c}}$ & $1.60 \pm 0.05^{\mathrm{bc}}$ & $1.51 \pm 0.02^{\mathrm{b}}$ & $1.34 \pm 0.02^{\mathrm{a}}$ \\
& & & & \\
878 & 2-Methylfuran & $0.64 \pm 0.02^{\mathrm{c}}$ & $0.50 \pm 0.03^{\mathrm{b}}$ & $0.42 \pm 0.04^{\mathrm{ab}}$ & $0.36 \pm 0.00^{\mathrm{a}}$ \\
943 & 2,5-Dimethylfuran & $0.22 \pm 0.03^{\mathrm{a}}$ & $0.18 \pm 0.01^{\mathrm{a}}$ & $0.25 \pm 0.04^{\mathrm{a}}$ & - \\
1075 & 2-Vinylfuran & $0.30 \pm 0.02^{\mathrm{b}}$ & $0.24 \pm 0.01^{\mathrm{ab}}$ & $0.20 \pm 0.02^{\mathrm{a}}$ & $0.19 \pm 0.00^{\mathrm{a}}$ \\
1149 & 2-Vinyl-5-methylfuran & - & - & $0.20 \pm 0.03$ & - \\
1247 & 2- (Methoxymethyl) furan & $0.34 \pm 0.02^{\mathrm{a}}$ & $0.33 \pm 0.01^{\mathrm{a}}$ & $0.35 \pm 0.03^{\mathrm{a}}$ & $0.31 \pm 0.01^{\mathrm{a}}$ \\
1493 & 2-Furancarboxaldehyde & $25.56 \pm 1.21^{\mathrm{a}}$ & $25.52 \pm 0.02^{\mathrm{a}}$ & $24.21 \pm 1.47^{\mathrm{a}}$ & $25.86 \pm 0.32^{\mathrm{a}}$ \\
1520 & Furfuryl formate & $0.47 \pm 0.04^{\mathrm{a}}$ & $0.46 \pm 0.02^{\mathrm{a}}$ & $0.42 \pm 0.01^{\mathrm{a}}$ & $0.40 \pm 0.01^{\mathrm{a}}$ \\
1542 & 1-(2-Furanyl)ethanone & $4.00 \pm 0.03^{\mathrm{a}}$ & $4.02 \pm 0.03^{\mathrm{a}}$ & $3.97 \pm 0.12^{\mathrm{a}}$ & $4.21 \pm 0.03^{\mathrm{a}}$ \\
1562 & 2-Furanmethanol acetate & $14.90 \pm 0.33^{\mathrm{a}}$ & $14.75 \pm 0.19^{\mathrm{a}}$ & $14.26 \pm 0.22^{\mathrm{a}}$ & $14.35 \pm 0.04^{\mathrm{a}}$ \\
\hline
\end{tabular}


Table 3. continue

\begin{tabular}{|c|c|c|c|c|c|}
\hline $\begin{array}{l}\text { Kovats } \\
\text { index }\end{array}$ & Volatile compound & $\begin{array}{l}\text { Soft water } \\
\text { (purified) }\end{array}$ & $\begin{array}{c}\text { Soft water } \\
\text { (bottled) }\end{array}$ & $\begin{array}{l}\text { Medium hard } \\
\text { water (mains) }\end{array}$ & $\begin{array}{l}\text { Hard water } \\
\text { (mains) }\end{array}$ \\
\hline 1610 & $\begin{array}{l}\text { 5-Methyl-2-furan } \\
\text { carboxaldehyde }\end{array}$ & $22.12 \pm 1.27 \mathrm{a}$ & $22.26 \pm 0.12^{\mathrm{a}}$ & $22.71 \pm 1.02^{\mathrm{a}}$ & $22.76 \pm 0.27 \mathrm{a}$ \\
\hline 1623 & 2,2'-Bifuran & $0.63 \pm 0.15^{\mathrm{a}}$ & $0.59 \pm 0.06^{a}$ & $0.55 \pm 0.07^{a}$ & $0.59 \pm 0.08^{a}$ \\
\hline 1632 & 2,2'-methylenebisfuran & $0.62 \pm 0.11^{\mathrm{a}}$ & $0.57 \pm 0.03^{\mathrm{a}}$ & $0.64 \pm 0.10^{a}$ & $0.56 \pm 0.05^{\mathrm{a}}$ \\
\hline 1693 & 2-Furanmethanol & $6.27 \pm 0.60^{\mathrm{a}}$ & $6.30 \pm 0.29^{a}$ & $6.50 \pm 0.27^{a}$ & $6.57 \pm 0.08^{a}$ \\
\hline \multirow[t]{2}{*}{1270} & $\begin{array}{l}\text { Dihydro-2-methyl-3(2H)- } \\
\text { furanone }\end{array}$ & $0.27 \pm 0.03^{\mathrm{a}}$ & $0.26 \pm 0.00^{a}$ & $0.29 \pm 0.02^{\mathrm{a}}$ & $0.27 \pm 0.01^{\mathrm{a}}$ \\
\hline & $\begin{array}{l}\text { Total } \\
\text { Ketone }\end{array}$ & $76.35 \pm 0.07^{a}$ & $75.97 \pm 0.12^{\mathrm{a}}$ & $75.00 \pm 0.94^{a}$ & $76.44 \pm 0.05^{\mathrm{a}}$ \\
\hline 1050 & 2,3-Pentanedione & $0.69 \pm 0.08^{\mathrm{a}}$ & $0.65 \pm 0.01^{\mathrm{a}}$ & $0.58 \pm 0.10^{\mathrm{a}}$ & $0.60 \pm 0.02^{a}$ \\
\hline \multirow[t]{2}{*}{1083} & 5-Methyl-3-hexanone & $0.25 \pm 0.01^{\mathrm{a}}$ & $0.24 \pm 0.01^{\mathrm{a}}$ & $0.21 \pm 0.04^{a}$ & - \\
\hline & $\begin{array}{l}\text { Total } \\
\text { Pyrazine }\end{array}$ & $0.94 \pm 0.09 \mathrm{a}$ & $0.89 \pm 0.02^{\mathrm{a}}$ & $0.79 \pm 0.14^{\mathrm{a}}$ & $0.60 \pm 0.02^{\mathrm{a}}$ \\
\hline 1302 & Methylpyrazine & $3.28 \pm 0.34^{a}$ & $3.13 \pm 0.05^{\mathrm{a}}$ & $3.04 \pm 0.16^{a}$ & $3.43 \pm 0.01^{\mathrm{a}}$ \\
\hline 1358 & 2,5-Dimethylpyrazine & $1.78 \pm 0.02^{\mathrm{a}}$ & $1.83 \pm 0.03^{a}$ & $1.81 \pm 0.06^{\mathrm{a}}$ & $1.90 \pm 0.00^{a}$ \\
\hline 1372 & Ethylpyrazine & $2.14 \pm 0.23^{\mathrm{a}}$ & $2.33 \pm 0.07^{a}$ & $2.86 \pm 0.30^{\mathrm{a}}$ & $2.39 \pm 0.09^{a}$ \\
\hline 1421 & 2-Ethyl-6-methylpyrazine & $2.48 \pm 0.12^{\mathrm{a}}$ & $2.54 \pm 0.08^{a}$ & $2.74 \pm 0.07 a$ & $2.61 \pm 0.01^{\mathrm{a}}$ \\
\hline 1429 & 2-Ethyl-5-methylpyrazine & $2.09 \pm 0.14^{\mathrm{a}}$ & $2.13 \pm 0.02^{\mathrm{a}}$ & $2.30 \pm 0.14^{\mathrm{a}}$ & $2.11 \pm 0.01^{\mathrm{a}}$ \\
\hline 1440 & 2-Ethyl-3-methylpyrazine & $0.64 \pm 0.00^{\mathrm{a}}$ & $0.61 \pm 0.00^{\mathrm{a}}$ & $0.71 \pm 0.02^{\mathrm{a}}$ & $0.62 \pm 0.01^{\mathrm{a}}$ \\
\hline \multirow[t]{2}{*}{1478} & $\begin{array}{l}\text { 3- Ethyl-2,5- } \\
\text { dimethylpirazine }\end{array}$ & $1.39 \pm 0.18^{\mathrm{a}}$ & $1.43 \pm 0.02^{\mathrm{a}}$ & $1.66 \pm 0.23^{\mathrm{a}}$ & $1.45 \pm 0.06^{\mathrm{a}}$ \\
\hline & $\begin{array}{l}\text { Total } \\
\text { Pyridine }\end{array}$ & $13.80 \pm 0.12^{\mathrm{a}}$ & $14.00 \pm 0.25^{\mathrm{a}}$ & $15.13 \pm 0.53^{\mathrm{a}}$ & $14.50 \pm 0.04^{\mathrm{a}}$ \\
\hline \multirow[t]{2}{*}{1221} & Pyridine & $0.10 \pm 0.01^{\mathrm{a}}$ & $0.11 \pm 0.01^{\mathrm{a}}$ & $0.14 \pm 0.02^{\mathrm{a}}$ & $0.19 \pm 0.02^{\mathrm{a}}$ \\
\hline & $\begin{array}{l}\text { Total } \\
\text { Pyrrole }\end{array}$ & $0.10 \pm 0.01^{\mathrm{a}}$ & $0.11 \pm 0.01^{\mathrm{a}}$ & $0.14 \pm 0.02^{\mathrm{a}}$ & $0.19 \pm 0.02^{\mathrm{a}}$ \\
\hline 1134 & 1-Methyl-1H-pyrrole & $0.18 \pm 0.02^{\mathrm{a}}$ & $0.20 \pm 0.05^{\mathrm{a}}$ & $0.15 \pm 0.03^{\mathrm{a}}$ & - \\
\hline 1665 & $\begin{array}{l}\text { 1-Methyl-1H-pyrrole-2- } \\
\text { carboxaldehyde }\end{array}$ & $1.64 \pm 0.04^{\mathrm{a}}$ & $1.64 \pm 0.02^{\mathrm{a}}$ & $1.78 \pm 0.08^{\mathrm{a}}$ & $1.65 \pm 0.02^{\mathrm{a}}$ \\
\hline \multirow[t]{2}{*}{1869} & $\mathrm{~N}$-furfuryl pyrrole & $1.66 \pm 0.18^{a}$ & $1.93 \pm 0.09 \mathrm{a}$ & $2.03 \pm 0.22^{a}$ & $1.71 \pm 0.06^{a}$ \\
\hline & $\begin{array}{l}\text { Total } \\
\text { Thiophene }\end{array}$ & $3.49 \pm 0.20^{\mathrm{a}}$ & $3.77 \pm 0.12^{\mathrm{a}}$ & $3.96 \pm 0.28^{\mathrm{a}}$ & $3.36 \pm 0.08^{a}$ \\
\hline \multirow[t]{2}{*}{1743} & 3-Ethyl-2-formylthiophene & $1.22 \pm 0.20^{\mathrm{a}}$ & $1.27 \pm 0.05^{\mathrm{a}}$ & $1.38 \pm 0.13^{\mathrm{a}}$ & $1.23 \pm 0.08^{a}$ \\
\hline & $\begin{array}{l}\text { Total } \\
\text { Unknown }\end{array}$ & $1.22 \pm 0.20^{\mathrm{a}}$ & $1.27 \pm 0.05^{\mathrm{a}}$ & $1.38 \pm 0.13^{\mathrm{a}}$ & $1.23 \pm 0.08^{a}$ \\
\hline 1533 & Unknown & $0.84 \pm 0.13^{a}$ & $0.63 \pm 0.16^{\mathrm{a}}$ & $0.47 \pm 0.02^{\mathrm{a}}$ & $0.83 \pm 0.08^{a}$ \\
\hline 1550 & Unknown & $0.67 \pm 0.02^{\mathrm{a}}$ & $0.69 \pm 0.01^{\mathrm{a}}$ & $0.69 \pm 0.00^{\mathrm{a}}$ & $0.70 \pm 0.00^{a}$ \\
\hline 1679 & Unknown & $0.23 \pm 0.07^{a}$ & $0.38 \pm 0.00^{a}$ & $0.30 \pm 0.06^{\mathrm{a}}$ & $0.36 \pm 0.01^{\mathrm{a}}$ \\
\hline \multirow[t]{2}{*}{1684} & Unknown & $0.66 \pm 0.01^{b}$ & $0.70 \pm 0.00^{\mathrm{b}}$ & $0.64 \pm 0.06^{\mathrm{b}}$ & $0.46 \pm 0.04^{a}$ \\
\hline & Total & $2.40 \pm 0.17^{a}$ & $2.39 \pm 0.15^{\mathrm{a}}$ & $2.10 \pm 0.14^{\mathrm{a}}$ & $2.35 \pm 0.06^{\mathrm{a}}$ \\
\hline
\end{tabular}

${ }^{1}$ : Analysis results were expressed as mean \pm standart deviation. The values with same letters within the same column are statistically similar $(P>0.05)$

It was revealed that furan compounds is the main volatile compounds of all Turkish coffee brews. On the other hand, no statistically significant difference was observed among the area percentage of furan compounds of Turkish coffee samples prepared with soft, medium hard and hard water $(P>0.05)$. The area percentage of total furan and furanone compounds were $76.35 \%$, $75.97 \%, 75.00 \%$, and $76.44 \%$ for Turkish coffee samples brewed with soft water (purified), soft 
water (bottled), medium hard water and hard water, respectively. The water used for Turkish coffee brewing significantly affected area percentage of 2-methylfuran, 2,5-dimethylfuran, 2-vinylfuran, and 2-vinyl-5-methylfuran ( $P$ $<0.05)$. The area percentage of 2 -methylfuran significantly decreased with increase in water hardness $(P<0.05)$. While 2,5-dimethylfuran was not determined in Turkish coffee prepared from hard water, 2,5-dimethylfuran area percentage of Turkish coffee brews with soft water and medium hard was not statistically different $(P>0.05)$. Turkish coffee samples brewed with medium hard and hard water had lower 2-vinylfuran area percentage than soft water Turkish coffee samples $(P<0.05)$. 2-vinyl-5-methylfuran was identified only in Turkish coffee prepared with medium hard water. In accordance with this study Ayseli et al. (2021) observed that furan compounds were main volatile compounds of Turkish coffee. Furan compounds contribute to the burnt, caramel, roasted and sweet aroma of coffee (Bicchi et al., 2002; Flament 2002; Schenker et al., 2002).

Volatile compounds from pyrazine group are the most common volatile compounds in Turkish coffee samples after furan group. The total area percentage of pyrazines changed between $13.80 \%-15.13 \%$. There was no statistically significant difference in area percentage of total pyrazines and each pyrazine compounds among Turkish coffee samples prepared with water having different hardness value. It was observed that water hardness value had no significant effect on pyrazines $(P>0.05)$. Pyrazines are significant part of coffee flavour compounds generated with roasting due to Maillard reaction between amino acids and reducing sugars with $\alpha$-diketones follow ring condensation as intermediates for transamination. Pyrazines are responsible from earthy and roasty flavour characteristics of coffee (Maeztu et al., 2001; Preedy, 2014; Gloess et al., 2018).

Total pyrrole content of Turkish coffee was not changed significantly depending on water type used in coffee brewing $(P>0.05)$. On the other hand, 1-methyl-1H-pyrrole was not determined in
Turkish coffee prepared with hard water. Pyrroles form as result of reaction of a 3-deoxyketose with amino compound after dehydration, ring closure. In coffee, pyrrole compounds contribute to coffee aroma notes (Mottram, 2007; Amanpour and Selli, 2016).

From aldehyde chemical class 2-methylbutanal and benzaldehyde were determined in all samples. Turkish coffee samples prepared with soft water contained less 2-methylbutanal area. The area percentage of benzaldehyde was not changed depending on water hardness $(P>0.05)$. Area percentage of 3-ethyl-2-formylthiophene from thiophene chemical class was not affected by water hardness significantly $(P>0.05)$. 3-ethyl-2formylthiophene area percentage of Turkish coffee samples were between $1.22 \%$ and $1.38 \%$.

2,3-pentanedione and 5-methyl-3-hexanone, which were member of ketone group were volatile compounds determined in Turkish coffee samples. 2,3-pentanedione was determined in all Turkish coffee samples and no statistically significant differences was observed among the area percentage of 2,3-pentanedione $(P>0.05)$. On the other hand, 5-methyl-3-hexanone was only identified in soft water and medium hard water used Turkish coffee samples. Ketone compounds in coffee contribute to fruity, butter, caramel, musty and mushroom-like aromas (López-Galilea et al. 2006).

Also, pyridine area percentage was not influenced by water hardness used in Turkish coffee preparation $(P>0.05)$. Pyridine area percentage of Turkish coffee samples was in $0.10 \%-0.19 \%$ range. Pyridine forms during coffee roasting process and higher pyridine content causes off flavour (Sanz et al., 2001). Pyridine gives burnt and smoky aromas to coffee (Flament, 2002).

For ideal coffee brewing SCAA (2009) advises that TDS value of water use in coffee preparation should be $150 \mathrm{mg} / \mathrm{L}$. Also, water having a TDS value higher than $250 \mathrm{mg} / \mathrm{L}$ should not be used in coffee preparation (SCAA, 2009). Volatile compound results of this study supported SCAA specification. Medium hard water used in this 
study had $161.33 \mathrm{mg} / \mathrm{L}$ TDS value which was found to be very close to $150 \mathrm{mg} / \mathrm{L}$. Turkish coffee brewed with medium hard water had the highest number of volatile compounds. On the other hand, Turkish coffee samples were prepared with hard water having TDS value higher than $250 \mathrm{mg} / \mathrm{L}$ had the least volatile compound.

Cluster analysis was applied to volatile compounds of Turkish coffee samples, and two main groups were determined. Turkish coffee prepared with medium hard water formed a group, other Turkish coffee samples formed another group. Turkish coffee samples prepared with soft water constituted a subgroup (Figure 1). PCA was used for investigation of sample separation due to the volatile compounds.
According to the PCA results, two main components that meet $92.70 \%$ of the total variation were determined (Figure 2). Turkish coffee samples prepared with bottled and purified soft water were separated from other samples with area percentage of 2-methylfuran, 2vinylfuran and 2,3-pentanedione. Volatile compounds namely; 2-vinyl-5-methylfuran, ethylpyrazine, 2-ethyl-5-methylpyrazine, 2-ethyl3-methylpyrazine, 3- ethyl-2,5-dimethylpirazine, 1-methyl-1H-pyrrole-2-carboxaldehyde and $\mathrm{n}$ furfuryl pyrrole were effective in differentiation of Turkish coffee samples prepared with medium hard water. Turkish coffee samples brewed using hard water were differentiated with 1-(2furanyl)ethanone, methylpyrazine, 2,5dimethylpyrazine and pyridine volatile compounds.

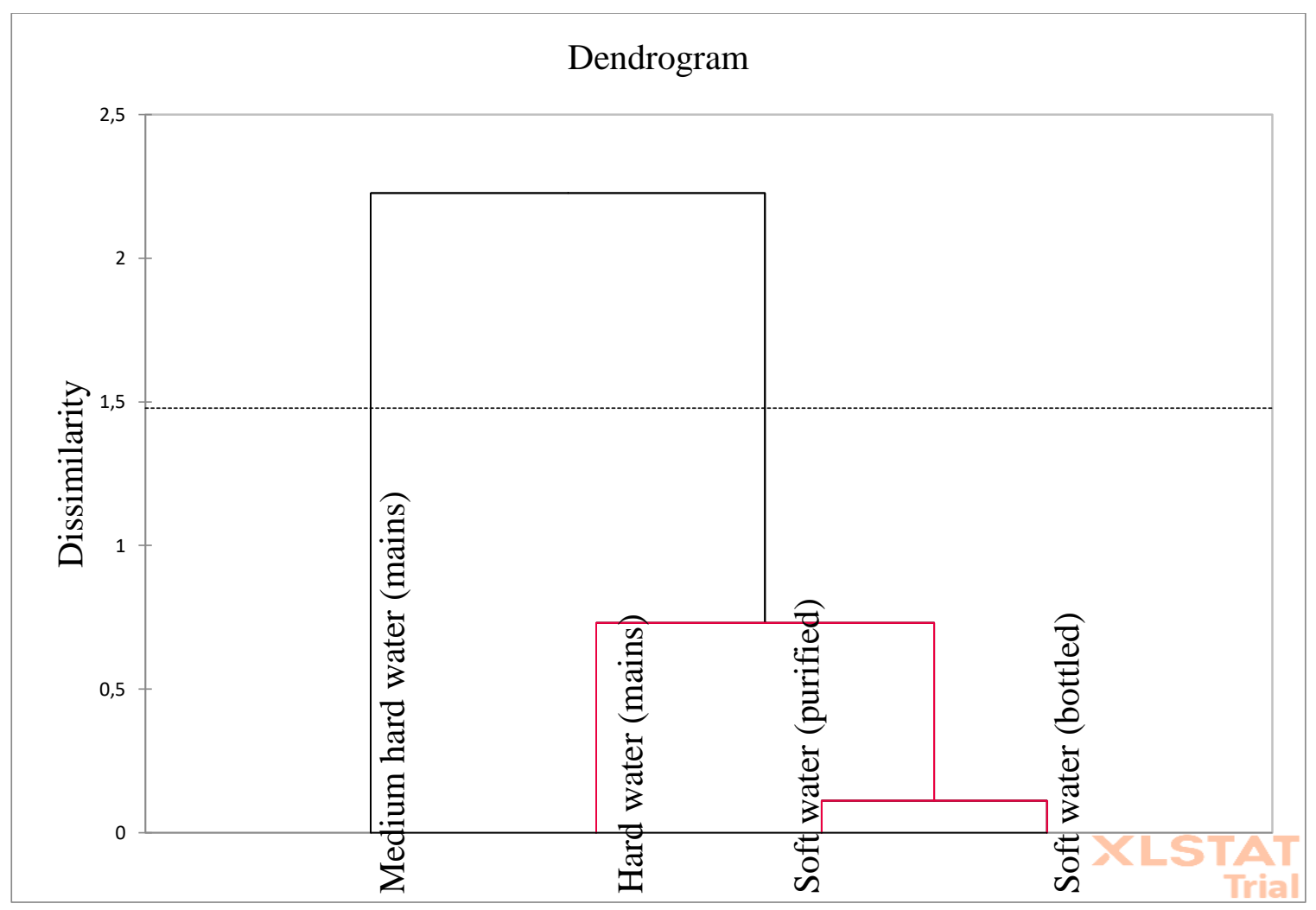

Figure 1. Cluster analysis result of volatile compounds of Turkish coffee samples 


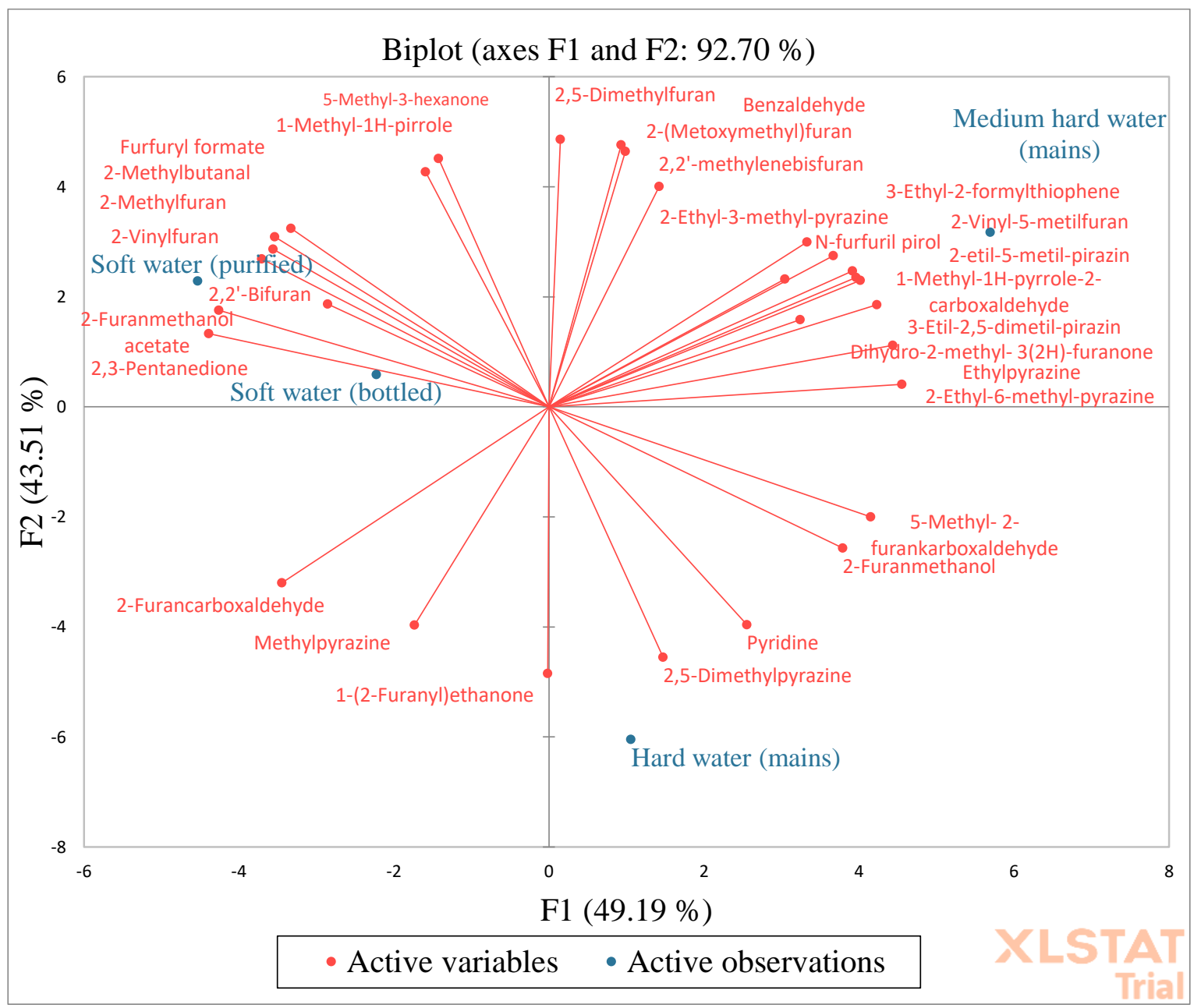

Figure 2. PCA of volatile compounds of Turkish coffee samples

\section{Sensory analysis}

The spider web diagram of sensory analysis results of Turkish coffee samples prepared with soft, medium hard, and hard water are given in Figure 3. Roasted coffee, roasted hazelnut, roasted almond, vegetable, spicy, earthy, citrus, sweet, sour and bitter sensory characteristics were perceived in all Turkish coffee samples. Roasted coffee and roasted hazelnut characters were intensely perceived in Turkish coffee prepared with medium hard water $(P<0.05)$. While the intensity of roasted almond character was low in Turkish coffee prepared with hard water $(P$ $<0.05)$, there was no statistically difference between Turkish coffee samples prepared with soft water and medium hard water $(P>0.05)$. The hardness of water did not have statistically significant effect on vegetable character of
Turkish coffees $(P>0.05)$. On the other hand, spicy character perceived intensely in Turkish coffees prepared with soft water and medium hard water $(P<0.05)$. No significant difference was observed in earthy character of Turkish coffee samples $(P>0.05)$. Intensity of citrus character of Turkish coffee prepared with hard water was lower than other Turkish coffee samples $(P<0.05)$. Whereas sweetness and sourness were perceived intensely in Turkish coffee samples brewed with soft water, the intensity of sweetness and sourness was low in Turkish coffee brewed with hard water $(P<0.05)$. Turkish coffee prepared with hard water was the most bitter, followed by Turkish coffee prepared with medium hard water and soft water, respectively $(P<0.05)$. 
In accordance with this study, Dadalı and Elmac1 (2021) determined that filter coffee prepared with hard water was bitter than other samples, and filter coffee prepared with soft water were very sour. When hard water is used in coffee preparation, due to carbonate and bicarbonates, bitter and flat coffee brew is obtained. Moreover, using soft water for coffee brewing results in excessive sourness. Since the alkalinity of the water reduces the acidity of the coffee, the sourness of the coffees prepared with hard water is less (Navarini and Rivetti, 2010).
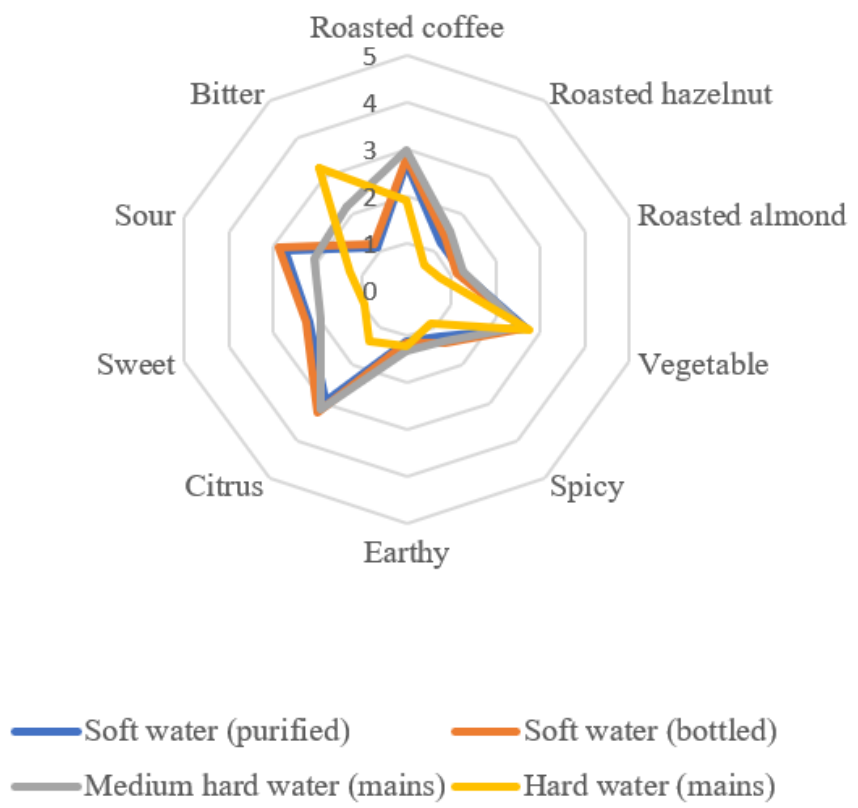

Figure 3. Spider web diagram of sensory characteristics of Turkish coffee samples

Cluster analysis was applied to sensory analysis results of Turkish coffee samples and two main groups were created. Turkish coffee samples brewed with hard water formed a group and Turkish coffee samples brewed with medium hard and hard water formed another group. Also, Turkish coffees prepared from purified and bottled soft water formed a subgroup (Figure 4). PCA was implemented to determine sensory characteristics that affected group forming. Biplot diagram of sensory characteristics of Turkish coffee samples is shown in Figure 5. Two main characters namely F1 (21.05\%) and F2 (77.30\%) explain $98.35 \%$ of total variation. Roasted coffee and roasted hazelnut sensory characteristics were effective in differentiation of Turkish coffee prepared with medium hard water. Turkish coffee samples brewed with soft water were separated from other Turkish coffee samples with sweet and sour characters. Moreover, bitter character was effective in grouping of Turkish coffee brewed with hard water.

\section{CONCLUSION}

The hardness of water used in the preparation of Turkish coffee affected both volatile compounds and sensory properties of Turkish coffee. Turkish coffee prepared with medium hard water had the highest number of volatile compounds, while Turkish coffee prepared with hard water had the least number of volatile compounds. Among the sensory properties, roasted coffee and roasted hazelnut were intensely perceived in Turkish coffee prepared with medium hard water, while the intensity of these characteristics were the lowest in Turkish coffee prepared with hard water. Turkish coffee samples did not differ in terms of vegetable and earthy characteristics. 
Turkish coffee prepared with hard water came into prominence with excess bitterness and lower roasted almond, spice, citrus fruit, sweet and sour characteristics. In Turkish coffee prepared with soft water, sweet and sour characteristics were perceived intensely, but the intensity of sour character was low.

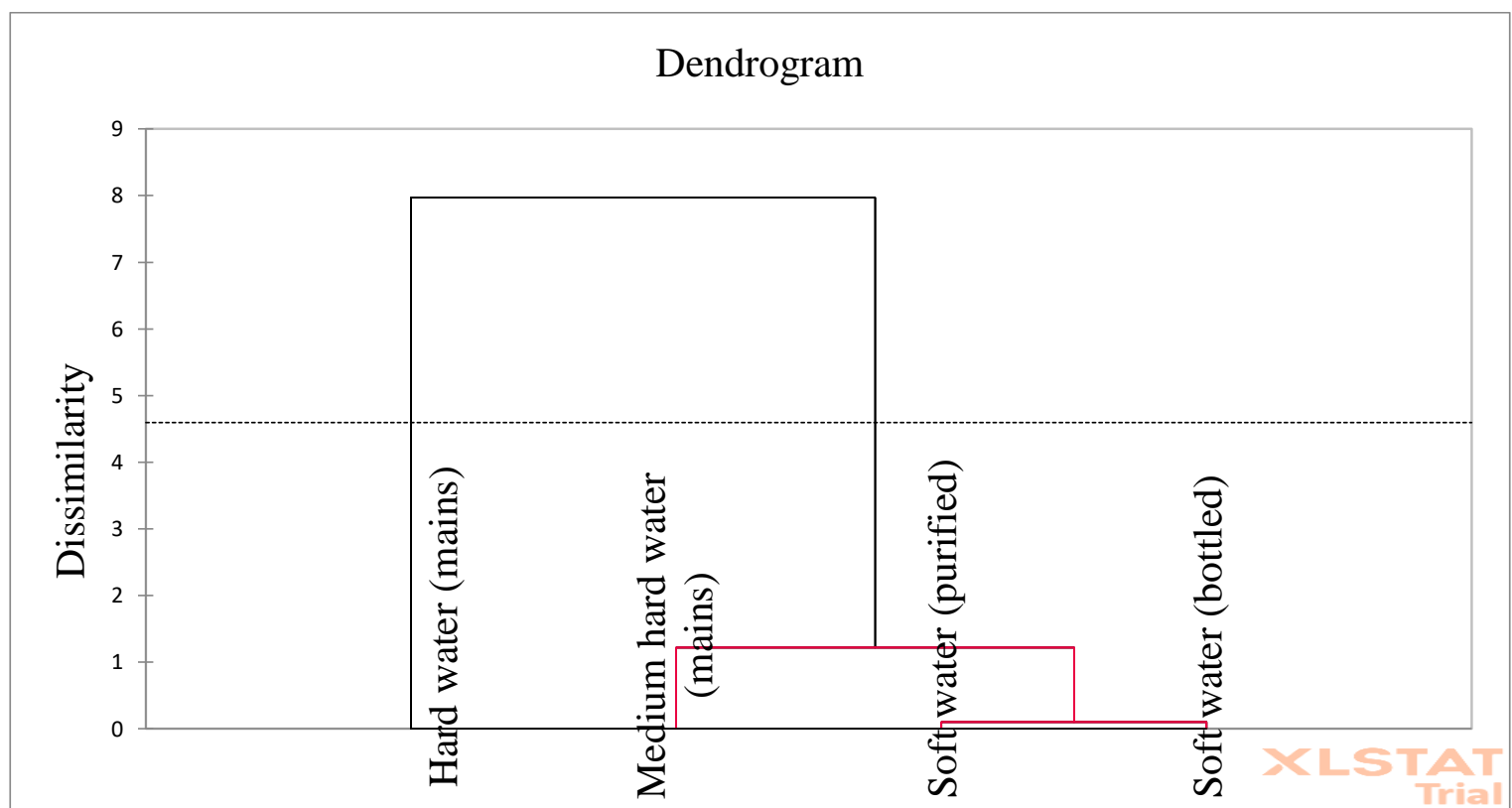

Figure 4. Cluster analysis results of sensory characteristics of Turkish coffee samples

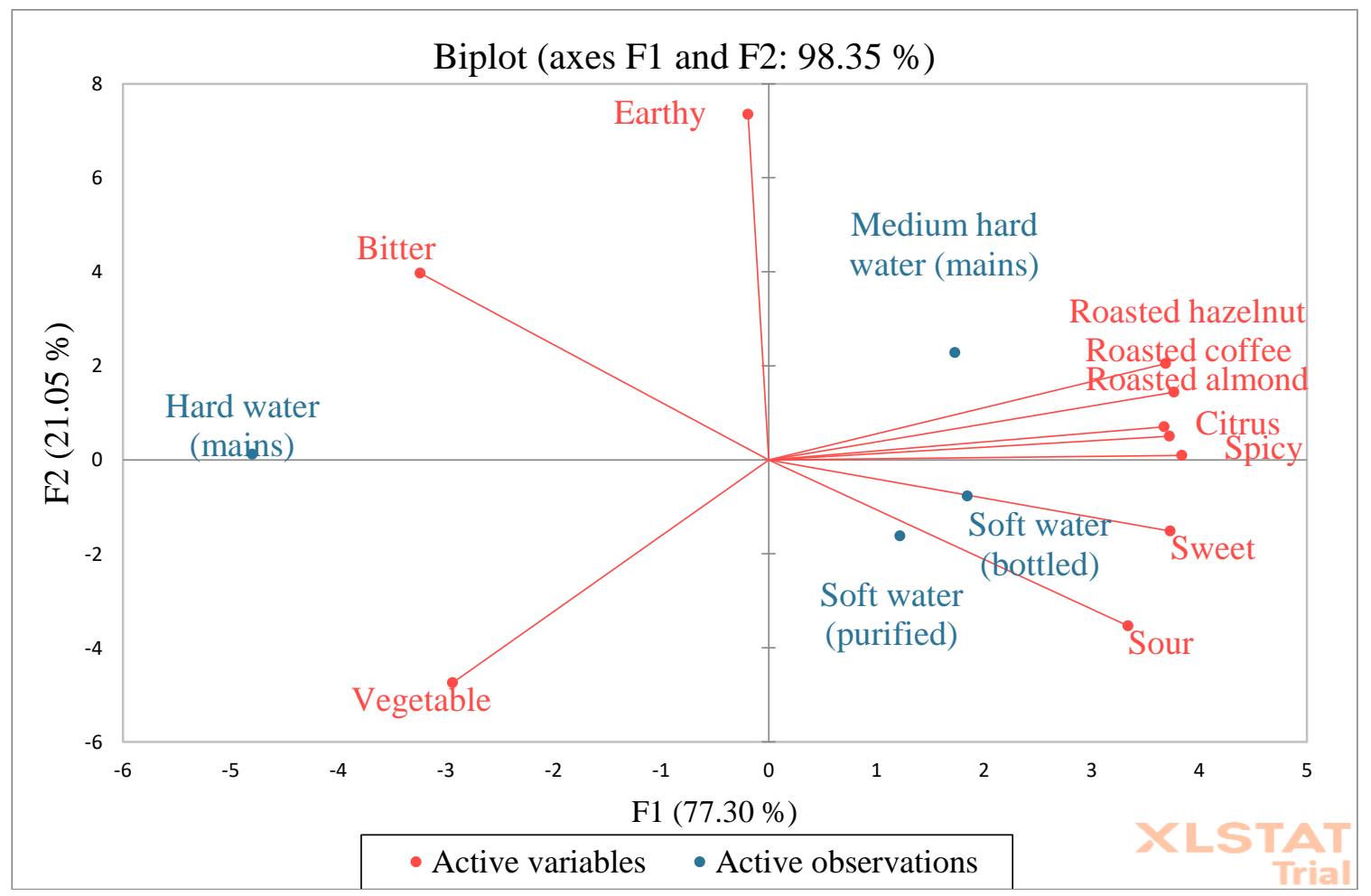

Figure 5. Biplot diagram of sensory characteristics of Turkish coffee samples 


\section{CONFLICT OF INTEREST}

Author declares no conflict of interest.

\section{REFERENCES}

Akgün, B., Arıcı, M., Çavuş, F., Karataş, A. B., Ekşi Karaağaç, H., \& Uçurum, H. Ö. (2021). Application of l-asparaginase to produce highquality Turkish coffee and the role of precursors in acrylamide formation. J Food Process Preserv, 45:e15486, doi: 10.1111/jfpp.15486.

Akiyama, M., Murakami, K., Hirano, Y., Ikeda, M., Iwatsuki, K., Wada, A., Tokuna K, Onishi M, Iwabuchi, H. (2008). Characterization of headspace aroma compounds of freshly brewed Arabica coffees and studies on a characteristic aroma compound of Ethiopian coffee. J Food Sci, 73(5): C335-C346, doi: 10.1111/j.17503841.2008.00752.x.

Altuğ Onoğur T, Elmac1 Y. (2015). Gidalarda Duyusal Değerlendirme. Sidas Medya, İzmir, Türkiye, 135s. ISBN:978-9944-5660-8-7.

Amanpour, A., Selli, S. (2016). Differentiation of volatile profiles and odor activity values of Turkish coffee and French press coffee. J Food Process Preserv, 40(5): 1116-1124, doi: 10.1111/jfpp.12692.

AOAC (1990). Official Methods of Analysis AOAC INTERNATIONAL. 15th Edition, Washington DC, the USA.

Ayseli, M. T., Kelebek, H., Selli, S. (2021). Elucidation of aroma-active compounds and chlorogenic acids of Turkish coffee brewed from medium and dark roasted Coffea arabica beans. Food Chem, 338: 127821, doi: 10.1016/j.foodchem.2020.127821.

Bicchi, C., Iori, C., Rubiolo, P., \& Sandra, P. (2002). Headspace sorptive extraction (HSSE), stir bar sorptive extraction (SBSE), and solid phase microextraction (SPME) applied to the analysis of roasted Arabica coffee and coffee brew. J Agric Food Chem, 50(3): 449-459, doi: 10.1021/jf010877x.

Cordoba, N., Fernandez-Alduenda, M., Moreno, F. L., Ruiz, Y. (2020). Coffee extraction: A review of parameters and their influence on the physicochemical characteristics and flavour of coffee brews. Trends Food Sci Technol, 96: 45-60, doi: 10.1016/j.tifs.2019.12.004.

Dadali, C., Elmac1, Y. (2021). The Effect of Water Hardness on Volatile Compounds and Flavour of Filter Coffee. Turkish Journal of Agriculture-Food Science and Technology, 9(2): 312-320, doi: 10.24925/turjaf.v9i2.312-320.3885.

Elmac1, I., Gok, I. (2021). Effect of three postharvest methods and roasting degree on sensory profile of Turkish coffee assessed by Turkish and Brazilian panelists. J Sci Food Agric, 1-9, doi: 10.1002/jsfa.11185.

Fibrianto, K., Ardianti, A. D., Pradipta, K., \& Sunarharum, W. B. (2018). The influence of brewing water characteristic on sensory perception of pour-over local coffee. IOP Conf Ser Earth Environ Sci, 102(1): 012095, doi: 10.1088/1755-1315/102/1/012095.

Flament, I. (2002). Coffee Flavor Chemistry. Wiley \& Sons, West Sussex, England, 424 p. ISBN: $978-0-$ 471-72038-6.

Gardner, D. G. (1958). Effect of certain ion combinations commonly found in potable water on rate of filtration through roasted and ground coffee. J Food Sci, 23(1): 76-84, doi: 10.1111/j.1365-2621.1958.tb17541.x.

Gloess, A. N., Yeretzian, C., Knochenmuss, R., Groessl, M. (2018). On-line analysis of coffee roasting with ion mobility spectrometry-mass spectrometry (IMS-MS). Int. J Mass Spectrom, 424: 49-57, doi: 10.1016/j.ijms.2017.11.017.

Hameed, A., Hussain, S. A., Ijaz, M. U., Ullah, S., Pasha, I., Suleria, H. A. R. (2018). Farm to consumer: factors affecting the organoleptic characteristics of coffee. II: postharvest processing factors. Compr Rev Food Sci Food Saf, 17(5): 1184-1237, doi: 10.1111/1541-4337.12365.

Hendon, C. H., Colonna-Dashwood, L., Colonna-Dashwood, M. (2014). The role of dissolved cations in coffee extraction. J Agric Food Chem, 62(21): 4947-4950, doi: 10.1021/jf501687c.

Jelen, H. (2012). Food flavors: Chemical, sensory and technological properties. CRC Press. Taylor \& Francis Group, Boca Raton, 504 p. 
Kivançli, J., Elmac1, Y. (2016). Characterization of Turkish-style boiled coffee aroma by gas chromatography and mass spectrometry and descriptive analysis techniques. Int $J$ Food Prop, 19(8): 1671-1686, doi: 10.1080/10942912.2015.1080726.

Küçükkömürler, S., Özgen, L. (2009). Coffee and Turkish coffee culture. Pak J Nutr, 8(10): 16931700.

López-Galilea, I., Fournier, N., Cid, C., \& Guichard, E. (2006). Changes in headspace volatile concentrations of coffee brews caused by the roasting process and the brewing procedure. $J$ Agric Food Chem, 54(22): 8560-8566, doi: 10.1021/jf061178t.

Maeztu, L., Sanz, C., Andueza, S., Paz de Pena, M., Bello, J., Cid, C. (2001). Characterization of espresso coffee aroma by static headspace GCMS and sensory flavor profile.J Agric Food Chem, 49(11), 5437-5444, doi: 10.1021/jf0107959.

Moroney, K., Lee, W., O 'Brien, S., Suijver, F., Marra, J. (2015). Modelling of coffee extraction during brewing using multiscale methods: An experimentally validated model. Chem Eng Sci, 137: 216-234, doi: 10.1016/j.ces.2015.06.003.

Mottram, D.S. (2007). The Maillard Reaction: Source of flavour in thermally processed foods. In Flavours and Fragrances: Chemistry, Bioprocessing and Sustainability, Berger, R.G. (ed.), Springer-Verlag, Berlin, pp. 269-284.

Navarini, L., Rivetti, D. (2010). Water quality for Espresso coffee. Food Chem, 122(2): 424-428, doi: 10.1016/j.foodchem.2009.04.019.
Pangborn, R.M. (1982). Influence of water composition, extraction procedures, and holding time and temperature on quality of coffee beverage. Lebensm-Wiss Technol, 15: 161-168.

Petracco, M. (2001). Beverage preparation: Brewing trends for the new millennium. In Coffee: Recent developments, Clarke, R., Vitzthum, O.G. (ed), Blackwell Science, Oxford, pp. 140-164.

Wei, F., Tanokura, M. (2014). Chemical Changes in the Components of Coffee Beans during Roasting. In Coffee in Health and Disease Prevention, Preedy, V. R. (Ed.), Academic Press, London, pp. 83-90.

Sanz, C., Ansorena, D., Bello, J., \& Cid, C. (2001). Optimizing headspace temperature and time sampling for identification of volatile compounds in ground roasted Arabica coffee. J Agric Food Chem, 49(3): 1364-1369, doi: 10.1021/jf001100r.

SCAA. (2009). Specialty Coffee Association of America. Water for Brewing Specialty Coffee. http://www.scaa. $\quad$ org/?d=waterstandards\&page $=$ resources (Accessed 18.04.2021).

Schenker, S.; Heinemann, C.; Huber, M.; Pompizzi, R.; Perren, R.; Escher, F. (2002). Impact of Roasting Conditions on the Formation of Aroma Compounds in Coffee Beans. J of Food Sci, 2002, 67(1): 60-66, doi: 10.1111/j.13652621.2002.tb11359.x. 